responses (mean $0.90 \pm 0.03$ ), but this was not significant. None of the patients in relapse showed significant migration inhibition with the splenic factor (see figure).

Those patients in remission 12 months after starting treatment showed no significant differences between remission migration response $(0.83 \pm 0.03)$ and pretreatment and post-treatment responses $(0.87 \pm 0.03$ and $0.81 \pm 0.02$ respectively). Eleven of the 24 patients $\left(46^{\circ}{ }_{0}\right)$ in remission showed significant migration inhibition compared with $12\left(50_{0}^{\circ}\right)$ at presentation.

The responses of patients in remission were significantly better $(\mathbf{P}<0.05)$ than the responses of patients in relapse.

\section{Discussion}

Possible antigens have been shownin non-cultured and cultured Hodgkin's disease tissues. ${ }^{3-7}$ Using the leucocyte migration technique, sensitisation to a factor in spleen obtained at necropsy from a patient with Hodgkin's disease was observed in about half the patients with malignant lymphoma tested. ${ }^{1}$ Sensitisation was less common in patients with other varieties of malignant disease $(10 \%)$, and rare in other inpatients and normal controls.

Patients with a positive immunological response to their tumour might be expected to have a better prognosis than those without such immunity. In our patients initial sensitisation to the splenic factor did not correlate with subsequent progress, nor was there any relation between presenting histological and clinical status and initial sensitisation responses. Nevertheless, when migration inhibition responses were retested during or after treatment and the patient's subsequent progress observed it was evident that enhancement of leucocyte migration inhibition at this stage was associated with good clinical progress. In subsequent assessment deterioration of response was found $m$ in patients relapsing whereas those in maintained remission? preserved their sensitisation to the splenic factor.

These findings suggest that sensitisation to the splenic factor, as yet unidentified, may be a useful index of response to treatment $\Rightarrow$ in patients with malignant lymphoma; deterioration of sensiti- $\stackrel{\vec{\rho}}{\rightarrow}$ sation may portend relapse of disease.

We are grateful to the consultant staff of Weston Park Hospital for access to patients under their care and to the Cancer Research $\mathbb{\Phi}$ Campaign (Yorkshire Branch) for financial assistance.

\section{References}

${ }^{1}$ Hancock, B W, Bruce, L, and Richmond, J, British Medical fournal, 1976, $1,556$.

2 S $\phi$ berg, M, and Bendixen, G, Acta Medica Scandinavica, 1967, 181, 247.

${ }^{3}$ Order, S E, Porter, M, and Hellman, S, New England fournal of Medicine, N 1971, 285, 471.

${ }^{4}$ Eshhar, Z, Order, S E, and Katz, D H, Proceedings of the National Academy of Science of the United States of America, 1974, 71, 3956. ${ }^{5}$ Long, J C, et al, Proceedings of the National Academy of Science of the $\mathrm{N}$

${ }^{6}$ Long, J C, Aisenberg, A C, and Zamecnik, P C, Proceedings of the National $\mathrm{O}$ Academy of Science of the United States of America, 1974, 71, 2285.

7 Long, J C, Aisenberg, A C, and Zamecnik, P C, Proceedings of the National Academy of Science of the United States of America, 1974, 71, 2605.

\title{
Closed mitral valvotomy
}

\section{KENNETH FRASER, MURDO A TURNER, BRIAN A SUGDEN}

British Medical fournal, 1976, 2, 352-353

\section{Summary}

The results of closed mitral valvotomy operations in 359 patients operated on from August 1957 to October 1974 were assessed at July 1975 . About $60^{\circ}{ }_{0}$ of the patients were in good health. These results suggest that there is still a place for closed mitral valvotomy in carefully selected cases.

\section{Introduction}

During the past 18 months the results of open mitral valvotomy were compared with the results of the closed operative procedure. ${ }^{12}$ Cogent arguments exist both for and against the closed technique, which is accepted by most surgeons as an acceptably safe means of relieving critical stenosis in suitable cases. The long-term results of both closed and open methods should ideally be concurrently compared for a true comparison to be drawn, but the reduced number of cases of mitral stenosis presenting at present would probably not provide reliable results in such a trial.

Department of Surgery, Western Infirmary, Glasgow G11 6NT KENNETH FRASER, CHM, FRCS ED, senior lecturer MURDO A TURNER, MB, FRCS, consultant cardiothoracic surgeon BRIAN A SUGDEN, MB, FRCS GLAS, surgical registrar
We therefore decided that information of some value might accrue from a further review of cases published in the British Medical fournal with, in addition, the results in patients operated on since these papers were published. ${ }^{3-5}$ This further review includes all patients with mitral stenosis who had a primary. closed valvotomy before October 1974.

\section{Patients and methods}

The results of closed mitral valvotomy operations performed by three surgeons in the Western Infirmary, Glasgow, in 1957-74ㄱ. were reviewed. The operation was carried out using the Tubbs mitraln valve dilator passed through the transventricular route. ${ }^{6}$ Of the $359 \mathrm{~N}$ patients who underwent this procedure the surviving 287 were $\omega$ available for assessment. Most were reviewed as outpatients and when this was not possible because of length of distance to travel or disability, information was obtained from the patient, his doctor, or both. Fourteen $(4 \%)$ of the group were not available for study. Three? patients were not traced after discharge from hospital and another 110 were lost at later stages of follow-up, some being under surveillance for up to nine years before they left the district. A few patients were traced through the Executive Council list owing to local population $\mathbb{\Phi}$ movement within the area.

\section{Results}

The 359 patients were divided into three groups: group 1 underwent operation in 1957-62, group 2 in 1963-8, and group 3 in 1969-74. Table I shows the decline in the number of operations performed more recently, thought to be due partly to the decline in the number of patients presenting with rheumatic heart disease but also to the increased availability of open heart surgery. 
There was an operative mortality rate of $4 \cdot 2^{\circ}$, for the total series, but this improved after 1965, since when there has been only one operative death. Excluding operative deaths, most of the 57 patients who died were in group 1 , as might be expected. Sixteen of the patients died from causes other than mitral valve disease when their cardiac status was satisfactory: six died of ischaemic heart disease; four of pneumonia, bronchitis, or pulmonary infarction; four of cancer; and two committed suicide. Of the other 41 , who died as a result of rheumatic heart disease, necropsy showed in two cases that aortic stenosis rather than mitral valve disease was responsible for death. Of the others 20 had calcified mitral valves at operation, and eight of these died after further surgery elsewhere (seven valve replacements and one redone valvotomy). Two of the five patients who died from cerebral embolism had had valve replacement before embolism, and in two other cases there had been an irregularity of anticoagulation therapy before death.

Many of these 57 patients survived a considerable time (table I). When information was adequate it showed that 18 had had a good or excellent result for a minimum of five years, and in only three patients was there no improvement at all after valvotomy.

TABLE I-Results of closed mitral valvotomy operation

\begin{tabular}{|c|c|c|c|c|}
\hline Group: & 1 & 2 & 3 & Total \\
\hline $\begin{array}{l}\text { No of patients } \\
\text { Operative deaths }\end{array}$ & $\begin{array}{r}141 \\
10\end{array}$ & $\begin{array}{r}141 \\
4\end{array}$ & $\begin{array}{r}77 \\
1\end{array}$ & $\begin{array}{l}359 \\
15\left(4 \cdot 2{ }^{\prime \prime} .\right.\end{array}$ \\
\hline $\begin{array}{l}\text { Late deaths: } \\
<5 \text { years } \\
5-10 \text { years } \\
>10 \text { years }\end{array}$ & $\begin{array}{l}13 \\
12 \\
12\end{array}>37$ & $\left.\begin{array}{r}6 \\
11 \\
1\end{array}\right\} 18$ & $2>2$ & $\left.\begin{array}{l}21 \\
23 \\
13\end{array}\right\} 57$ \\
\hline Total survivors & 94 & 119 & 74 & 287 \\
\hline
\end{tabular}

The assessment of 287 survivors is shown in table II. Fourteen were lost to follow-up, but six had an excellent result for two to five years, and four had an excellent result for five to 10 years. The clinical results were graded as follows: excellent-asymptomatic; good-acceptable, but minor, limitation of exercise tolerance; poor-deteriorating exercise tolerance despite drug treatment.

Table II shows that $59^{\prime \prime}$ " of the remaining 273 survivors had an excellent result, and there was little deterioration in this figure over a longer follow-un period-54" "still being excellent in group I.

TABLE II-Assessment of 287 surviving patients. Results are numbers (and percentages of 273 )

\begin{tabular}{l|c|c|c|c}
\multicolumn{1}{c|}{ Group: } & 1 & 2 & 3 & Total \\
\hline Survivor assessment: & & & & \\
Excellent & $45(54)$ & $73(63)$ & $43(59)$ & $161(59)$ \\
Good & $17(20)$ & $26(22)$ & $11(15)$ & $54(20)$ \\
Poor & $11(13)$ & $9(8)$ & $13(18)$ & $33(12)$ \\
Further operation & $11(13)$ & $8(7)$ & $6(8)$ & $25(9)$ \\
Lost to follow-up & 10 & 3 & 1 & 14 \\
\end{tabular}

Overall 58 patients $\left(21^{\circ}{ }_{0}\right)$ were classified as having a poor result, but this included those patients who required further operations, the results of which are shown in table III. Excluding those with a good result and those lost to follow-up after this further procedure, only $13.6^{\circ}$ o had a poor result at the time of review. Eight of those with poor results were awaiting cardiac catheterisation and 12 were awaiting further cardiac surgery.

Of the 58 patients classed overall as having a poor result eight had calcified valves and 26 had densely fibrous, funnelled valves at operation.

TABLE III-Results of additional operative procedures

\begin{tabular}{l|c|ccccc|c}
\hline \multicolumn{1}{c|}{ Procedure } & $\begin{array}{c}\text { No of } \\
\text { patients }\end{array}$ & $\begin{array}{c}\text { No of } \\
\text { deaths }\end{array}$ & $\begin{array}{c}\text { Very } \\
\text { good }\end{array}$ & Good & Poor & $\begin{array}{c}\text { Not } \\
\text { known }\end{array}$ \\
\hline Valvotomy redone & 9 & 1 & 2 & 2 & 2 & 2 \\
$\begin{array}{l}\text { Open valvotomy } \\
\text { Valve replacement }\end{array}$ & 5 & 0 & 2 & 5 & 1 & 2 \\
\hline
\end{tabular}

\section{Discussion}

Inevitably some changes in patient management took place over the 17 years. A reduction in the complication of cerebral embolus at the time of operation occurred when snaring the carotid and innominate arteries in 1961 was introduced for patients with atrial fibrillation or those who had had an embolus.

In 1965, after Smith et al had proved the efficacy of anticoagulant treatment, ${ }^{7}$ all patients in atrial fibrillation and all patients with previous emboli were put on to anticoagulant treatment for at least eight weeks before valvotomy. The Thrombotest was the guide to satisfactory anticoagulation, which was held at $10-12^{\circ}{ }_{0}$. This regimen had the effect of totally removing fresh clot from the operative site and reduced the amount of organised thrombus considerably: no deaths from embolism occurred after the introduction of anticoagulant treatment. No untoward serious complications resulted from this treatment.

Reviewing the results of the entire series of 359 patients, this operation had an acceptable mortality rate and a satisfactory success rate: $60^{\circ}$ of these patients were in good health. It should be possible to select those patient most likely to have a satisfactory result with the present investigative procedures available. Any patient with a calcified or fixed fibrous valve should not be considered for a closed valvotomy.

Careful follow-up of patients at regular intervals is also important, not only for treating any recurrent symptoms but also to prevent unassociated causes of deterioration. In no fewer than nine patients with a poor result from their closed valvotomy, weight increase was apparent and coincidental with deterioration in their wellbeing. In a further four cases there were underlying psychiatric problems thought to account for some symptoms. Regular follow-up of outpatients allows for early dietary or psychiatric advice when necessary and may help prevent such deterioration.

With the present economic situation another important factor that must be considered is the cost to the National Health Service. All operations reviewed in this series were carried out within a general surgical unit, in which the staff were interested in cardiothoracic surgery. The operations were often performed at the start of a general surgical theatre list, and after operation the patients were usually managed in the general ward. Only in the past few years have intensive care unit facilities been available, and they have been used only when postoperative problems have arisen.

The operation of closed valvotomy for mitral stenosis should therefore be the procedure of choice for those patients with non-calcified pliable valves, the results and costs of this operation comparing favourably with those of open heart procedures.

Most of the operations were carried out by KF and MAT, but our thanks are due to $\mathrm{Mr}$ Douglas H Clark, who did some of the operations. We thank the many cardiologists and physicians for their help and co-operation; also a multitude of supporting surgical, anaesthetic, nursing, and physiotherapy staff. We thank Mrs Aitchison for organising the case records over the years and Mrs Isaac and Miss Fallon for additional secretarial help.

\section{References}

${ }^{1}$ International Meeting of the American College of Chest Physicians London, 1974

2 Lennox, S C, Bennett, J G, and Cheung, D, Paper given at the Annual Meeting of the Society of Thoracic and Cardiovascular Surgeons of Great Britain and Ireland, Glasgow, September, 1975.

${ }^{3}$ Fraser, K, and Kerr, I S, British Medical fournal, 1961, 2, 339.

4 Fraser, K, and Kerr, I S, British Medical fournal, 1962, 2, 443.

5 Fraser, K, Kerr, I S, and McGuinness, J B, British Medical fournal, $1964,2,421$.

${ }^{6}$ Logan, A, and Turner, R W D, Lancet, 1959, 2, 874.

$?$ Smith, A B, et al, British Heart fournal, 1965, 27, 618. 